\title{
Differentiation of First- and Second-set Grafts of Neonatal Testis, Ovary, Intestine and Spleen Implanted Beneath the Kidney Capsule of Adult Albino Rat Hosts'
}

\author{
ANNYE CANNADY BUCK \\ Department of Zoology, The University of Michigan, \\ Ann Arbor, Michigan ${ }^{2}$
}

Recent work on the mechanisms governing success or failure of transplanted vertebrate tissues has been increasingly influenced by the concept of transplantation immunity. While autografts are commonly successful, homografts and heterografts usually degenerate or are sloughed after a short period of toleration by the host (Gibson and Medawar, '43; Medawar, '44, '45; Billingham, Brent, Medawar, and Sparrow, '54; Steinmuller, '61a). Not only are homografts eventually rejected, but this reaction occurs more rapidly in a second homograft which has followed a first graft from the same donor. This second-set response has been reported by many workers (Gibson and Medawar, '43; Dempster, '53b; Billingham, Brent, and Medawar, '54; Simonsen, '55; Lewis, Murray and Couch, '57).

In contrast to the experience that homografts are usually unsuccessful, several investigators in the past few years have been able experimentally to induce animals to tolerate homografts of normal tissues (Billingham, Brent, and Medawar, '56a; Medawar and Woodruff, '58; Krohn, '58; Billingham and Silvers, '61) as well as to enhance homografts of neoplastic tissues (Snell, Cloudman, Failor, and Douglas, '46; Kaliss, '55; Snell, Winn, Stimpfling, and Parker, '60). What are the mechanism of transplantation immunity or acquired tolerance?

Three major theories, reviewed by Medawar ('43), have been advanced to explain the mechanism of resistance to homografts: (1) the "blood group" theory (Davis, '17; Masson, '18), (2) the "local cellular" theory (Loeb, '45), and (3) the "actively acquired immunity" theory, supported by the work of Schöne ('12), Holman ('24), Stone ('42), and Gibson and Medawar ('43). Current thinking supports the third theory, which holds that homografts, which are genetically different from the host tissue, act as antigens and elicit an immunologic response by the host. The work of Medawar ('44, '45) gave conclusive evidence for actively acquired immunity against homografts. Although this theory is generally accepted, we still do not know how the immune mechanism operates. As reviewed by Lawrence ('60), homograft rejection could possibly be mediated by serum antibodies, by immune factors bound to lymphoid cells, by the combined effects of serum antibodies and cell-bound immune factors, or by an immune response peculiar to itself. Two systems of antigens - those which cause transplantation immunity ( $\mathrm{T}$ antigens) and those which elicit serum antibodies ( $\mathrm{H}$ antigens) - have been distinguished (Billingham, Brent, and Medawar, '56b). Gorer ('56) has indicated that the type of homograft, whether leucocytic cells, as cites tumor cells, or solid tissue graft, influences the kind of immune mechanism involved. Brent, Brown, and Medawar ('59) have expressed the opinion that homograft reaction against solid tissue grafts is a cell-mediated immune mechanism which is analogous to that operative in delayed-type sensitivity.

1 Based on a dissertation submitted in partial fulfillment of the requirements for the degree of Doctor of Philosophy in The University of Michigan, 1960. The research was aided by a fellowship from the National Medical Fellowships, Inc., through funds appropriated by the National Foundation.

appropriated by the National Foundation. Medical College, Nashville, Tennessee. 
Immunity to orthotopic skin homografts has been adoptively transferred by activiated lymphoid cells (Billingham, Brent, and Medawar, '54, '56; Steinmuller, '61b; Billingham, Silvers, and Wilson, '62), and by leucocyte extracts (Lawrence, Rapaport, Converse, and Tillett, '60). There is also experimental evidence which demonstrates the presence of humoral antibodies in some experimental animals which have received homografts, particularly of tumors (Amos, Gorer, and Mikulska, '54; Gorer, '55). Terasaki, Cannon and Longmire ('60) have evidence that humoral antibody is evoked by solid homografts of normal skin. Successful adoptive transfer of immunity against skin homografts with antisera has been accomplished (Stetson and Demopoulos, '58; Chutná, '61), though the reaction seems to be different from the accelerated rejection characteristic of second homografts.

The present investigation was undertaken in order to test the reaction of host against graft and of graft against host after primordia of various organs were implanted either singly or in combinations into adult albino rat hosts. The experiments are an extension of the work of Larkin ('60) who investigated the fate of grafts of testis implanted beneath the kidney capsule of adult male rats. The present investigation has tested the specificity of antigens (?) from different organs by comparing the effects of initial grafts of testis, ovary, spleen, or intestine followed by a second graft of any of these four organs. Organs from 4-day-old neonatal donors were selected because they were still differentiating and yet probably incapable of producing antibodies against the host. Woodruff and Simpson ('55) have shown that in the rat the antibody mechanism is not fully established until 14 days after birth. At four days of age, however, donor tissues could be antigenic to adult host, in which the immunity mechanism is already established. The four organs tested all grow successfully when transplanted singly (Harris and Eakin, '49; Billingham and Parkes, '55; Crouse, '56; Macintyre, '56; Larkin, '60; Kammeraad, '42; Greene, '55). Presumably they differ in antigenicity and in content of immunologically competent cells. The spleen, for example, is both powerfully antigenic and active in producing antibodies (Simonsen, '55 and Castermans, '58).

\section{MATERIALS AND METHODS}

Albino rats used in this investigation were secured from the Holtzman Company, Madison, Wisconsin. Males approximately one year of age were used as hosts for grafting experiments. To obtain newborn rats used as sources of donor organs, adult females were mated with males at times calculated to result in litters on given dates. Inseminations were confirmed by vaginal smears, and length of gestation reckoned as 21 days from insemination. Fertility was enhanced by feeding female breeders a special diet of wheat germ cereal, oranges, carrots, and pig liver or pig heart, beginning three or four weeks prior to mating and continuing throughout pregnancy. Litters were used for donor organs four days after birth. Spleen, ileum and testis were dissected from male donors. Ovaries were obtained from females in the same litter.

The first procedure was to excise organs from etherized neonatal donors. Different organs were placed in separate sterile Petri dishes containing sterile Ringer's solution. Both testes of male donors were removed and transferred to a dish of Ringer's solution. The epididymis was then removed, and the testis was transferred to a fresh dish of Ringer's where it was bisected. Intestine was prepared by removing a section of the caudal portion of the ileum, placing it in a Petri dish and flushing its lumen by means of a small pipette. It was then transferred to a second dish and cut into segments approximately $2 \mathrm{~mm}$ in length. If necessary, the segments were flushed again and transferred to a third dish. Spleens were removed and cut into small pieces, approximately $2 \times 2 \mathrm{~mm}$, which were kept in Ringer's solution until ready for use. Ovaries with surrounding bursa and oviduct were dissected from females and placed in a dish of Ringer's solution. Bursa and oviduct were removed from the ovary under a dissecting microscope, and the ovary was transferred to a dish of fresh solution, where it remained until ready for grafting. 
Host animals were then anesthetized with ether, shaved in the area where the incision was to be made, and placed in a dissecting pan lined with clean towels. After the bare skin was bathed with $70 \%$ alcohol, a transverse incision about threefourths of an inch in length was made through the dorsolateral wall of the abdomen just caudad of the last rib. With a loop improvised from a piece of number 12 copper wire, according to the technique used by Macintyre ('56) and Larkin ('60), the kidney was lifted out of the peritoneal cavity and immediately covered with sterile cotton soaked with Ringer's solution. The desired piece of donor organ was then picked up on one prong of jeweler's forceps modified so that the prong had a blunt end. Tissue was held in a droplet of Ringer's solution on this blunt end. Another pair of jeweler's forceps was used to pick up the kidney capsule, and with the pointed prong of the modified forceps the kidney capsule was punctured. The forceps were then turned in the hand so that the clinging tissue could be inserted through the puncture and deposited just beneath the capsule. The muscular layers of the incision were sutured with no. 4-0 surgical thread, the outer skin layer was clamped together with wound clips, and the area of the incision was coated with celloidin to protect it.

Control animals received a single graft, always to the left kidney. Hosts for two grafts received the first under the left kidney capsule and the second under the right. Single grafts were allowed to grow for periods of two, four and six weeks. In hosts for double grafts, the first graft was allowed to grow two weeks and then the second graft was implanted. Animals were autopsied and both grafts recovered four weeks after the second operation. Recovered grafts were fixed in Bouin's fixative, embedded in paraffin, sectioned at $6 \mu$, and stained with Heidenhain's azan triple stain.

\section{RESULTS}

\section{Histology of donor organs when implanted}

Testis. The four-day-old testis contained closely packed seminiferous tubules, separated by septulae of connective tissue.
Sectioned tubules appeared to be solid and made up chiefly of undifferentiated cells in the periphery and fewer large cells scattered mostly toward the interior of the tubule (fig. 1). Hargitt ('26) considered these large cells as possible primordial germ cells. It is believed that they degenerate during normal development and that the maturing sex cells of the adult differentiate from cells contributed by smaller peripheral cells of the young seminiferous tubules.

Ovary. The four-day-old ovary was less than $1 \mathrm{~mm}$ in length. The germinal epithelium appeared to be two or three cells in thickness except at the hilus, where it was reduced to a single layer of cuboidal cells. The secondary cortex and definitive medulla were present, and a delicate irregular tunica albuginea intervened between the germinal epithelium and the cortex. Sections of the cortex revealed distinct cellular cords (Pflüger's tubes) composed of large oogonia and a few undifferentiated cells (fig. 2). In some cords, the oogonia were devoid of follicle cells. Primary follicles, in which young primary oocytes were surrounded by a single layer of follicle cells, were sometimes present. Occasionally a large oogonium was observed in the layer of germinal epithelium. The definitive medulla, a fibrous vascular stroma, was devoid of oogonia.

Intestine. The lower intestine at four days was approximately $2 \mathrm{~mm}$ in diameter. A typical cross section (fig. 3) revealed a lumen and villi lined by columnar cells, having striated borders, and goblet cells. Low columnar cells lined the glands of Lieberkühn. Many epithelial cells contained mitotic figures. The lamina propria filled the cores of villi and could be seen between the glands. External to the thin vascular submucosa was a thicker layer of smooth muscle which had differentiated into an inner circular layer and an outer longitudinal layer. The longitudinal muscle layer was covered externally by a thin serosa. Lymphocytes were present in both the lamina propria and the submucosa.

Spleen. The four-day-old spleen (fig. 4) was surrounded by a relatively thin capsule from which thin trabeculae extended inward. The splenic tissue was still generally myeloid in character, although oc- 
casionally there was an indication of white pulp developing around an artery. There was no differentiation of red pulp. Myeloid elements in the rat's spleen reach their maximum development three weeks after birth and then gradually begin to disappear (Maximow and Bloom, '57).

\section{Fate of single grafts}

Testis. Single grafts of testis recovered after two weeks had increased in size and differentiated to the extent that most of the seminiferous tubules had lumina or were in the process of forming them. Spermatogonia had proliferated and three to five layers of cells could be counted from the basement membrane of the tubule to the lumen. Many cells were fixed in the process of division. In some tubules many spermatogonia with pycnotic nuclei were detached from the wall and apparently were being sloughed into the lumen. In several tubules primary spermatocytes, some showing signs of degeneration, had differentiated. All grafts were well vascularized, but there was a variation in the amount of connective tissue present.

Growth and differentiation in grafts of four weeks were more advanced than after two weeks. Degeneration and sloughing of cells into seminiferous tubules apparently had continued, but there were still three to five layers of cells. According to Hargitt ('26), degeneration and sloughing of cells seem to be a part of the process of lumen formation. Although most primary spermatocytes were massed in the lumen and appeared to be degenerate, some appeared normal in tubules with little or no cavitation. Occasionally primary spermatocyes in the first meiotic division (fig. 5) were observed. No spermatids were observed, whereas they were differentiated in the testis of a normal rat of comparable age. A few Sertoli cells were identified in the peripheral layer of cells next to the basement membrane.

Seminiferous tubules in grafts of six weeks had very large lumina, indicating abundant sloughing. Most tubules had no more than two or three irregular layers of cells. Some pycnotic primary spermatocytes were still present. Presumably the peak of differentiation in single grafts was reached by four weeks. After six weeks cell proliferation had decreased and many cells had degenerated and sloughed, thereby leaving tubules with wide lumina. Normal testis at a comparable age had seminiferous tubules with complete spermatogenesis.

Ovary. Single grafts of ovary after two weeks contained many enlarged primary oocytes invested with several layers of follicle cells. The cortical stroma in these grafts was more extensive than in the normal ovary, and well vascularized connective tissue filled the area between the grafted ovary and the host kidney. Germinal epithelium could not easily be distinguished, but recent proliferation of oogonia was evident. Follicles of the grafted ovary were in the same range of size as those of a normal ovary at this age.

In grafts of four weeks (fig. 6) several ovarian follicles, with numerous follicular cells, were vesicular. Thecal cells had surrounded the follicle, but the theca externa was not easily distinguished from the theca interna. Follicular atresia was pronounced and accompanied by extensive interstitial gland formation. These changes occurred in the normal ovary of the same age, but not so frequently. Some grafts recovered after four weeks had undergone much degeneration and were hardly recognizable as ovarian. They were essentially a mass of connective tissue heavily infiltrated with lymphocytes.

By six weeks all ovarian grafts had undergone much degeneration. They appeared as large masses of connective tissue in which certain areas were void of lymphocytes and reticular cells apparently had been transformed into fat cells. Several cysts, varying from large to small, were observed.

Intestine. Single grafts of intestine at two weeks exhibited epithelial proliferation. Many cells were in the process of dividing and goblet cells were prominent. Villi were pronounced. The lamina propria contained many lymphocytes but apparently not organized into distinct nodules. Some lymphocytes in the epithelium appeared to be fixed in the process of migrating through it into the lumen of the intestine. Submucosa and muscularis were thicker than normal. Connective tissue between the graft and host often in- 
vaded the kidney cortex, and parts of the uriniferous tubules in this section appeared degenerate.

In some four-week single grafts villi were more numerous. Many goblet cells were filled with mucus, and Paneth cells with secretory granules occurred regularly in the bottom of the glands of Lieberkühn (fig. 7). Connective tissue with masses of lymphocytes was concentrated at the junction of the graft and host.

Some grafts were degenerate at two and four weeks, but all were degenerate at six weeks. In cross section such degenerate implants could be identified as a hollow ring of connective tissue with interwoven collagenous fibers. Lymphocytes and plasma cells were present within this ring of connective tissue. Fragments of various layers of the intestinal wall could be identified.

Spleen. No two-week single grafts of spleen were recovered. Four-week grafts (fig. 8) were degenerate and surrounded by a zone of connective tissue infiltrated with lymphoid cells, neutrophils and macrophages. Sections of splenic tissue within the surrounding connective tissue contained no lymphatic nodules but resembled red pulp interspersed with many neutrophils and macrophages. Throughout the graft and also in the area where proliferating connective tissue had invaded the renal cortex there were numerous macrophages containing golden brown particles of hemosiderin.

No grafts were recovered at six weeks, but an accumulation of dense connective tissue infiltrated with macrophages indicated the site of implantation in the host kidney.

\section{Fate of double grafts}

The reaction of host against grafts may vary in severity from complete destruction of graft to no adverse reaction. Histological appearance of the graft and surrounding host tissues were the basis for the analysis of host reactions summarized in tables 1-4.

\section{Testis as second graft}

Grafts of testis preceded by testis. All second grafts, which had been implanted for four weeks, appeared healthy and had grown considerably, but differentiation of spermatocytes was retarded (fig. 9) when compared with single grafts of testis at four weeks (fig. 5). Sections from seven of the ten grafts recovered revealed no primary spermatocyes. Three grafts, however, had a few pycnotic and sloughed spermatocytes in a few of the tubules. There were two to five layers of cells bordering the lumina of seminiferous tubules. Spermatogonia nearest the lumen were often detached and pycnotic, but those nearest the periphery of the tubule were normal and apparently undergoing mitosis. All grafts were well vascularized and only two of the ten showed an excess proliferation of connective tissue at the junction of graft and kidney where the kidney cortex also had been invaded.

First grafts, which had grown for six weeks, still had primary spermatocytes, although they were degenerate and isolated in the lumina of tubules. These grafts of testis did not appear to be any different from single grafts of the same age.

Grafts of testis preceded by ovary. All second-set grafts of testis preceded by ovary, except the one which had undergone a very severe homograft reaction, contained seminiferous tubules with some primary spermatocytes (fig. 10). These cells usually were degenerate and less numerous than in the four-week single grafts (fig. 5).

First-set grafts of ovary varied. Six of the nine grafts showed better growth and differentiation than any single grafts of ovary recovered at six weeks. Some large vesicular follicles were slightly compressed, probably as a result of some pressure by the renal capsule. One multiovulare follicle was observed.

Grafts of testis preceded by intestine. Six of the nine grafts of testis experienced a very severe homograft reaction. They consisted of a mass of connective tissue highly infiltrated with lymphocytes and were hardly recognizable as testis (fig. 11). Usually most of the tubules had been destroyed. If individual tubules remained, they had no more than one or two irregular layers of cells lining the lumen of the tubule. No primary spermatocytes were observed in any of these six grafts. Both 
grafts which had experienced a very mild homograft reaction had seminiferous tubules with primary spermatocytes present. These did not vary greatly from single grafts of a comparable age. The one graft which had undergone a reaction of slightly greater intensity showed evidence of the destruction of interstitial tissue. Tubules were intact but spermatocytes were few. Connective tissue was common at the junction of the graft and host kidney as well as at the outer margin of the graft.

First-set grafts of intestine recovered were severely damaged, but they looked about like single grafts after six weeks.

Grafts of testis preceded by spleen. No primary spermatocytes were present in second grafts of testis which had undergone a very severe homograft reaction (fig. 12). In grafts where the reaction was less severe, retained seminiferous tubules contained some primary spermatocytes. Frequently connective tissue with many lymphocytes had invaded the host kidney cortex.

With one exception, all first-set grafts of spleen were deteriorated. Grafted tissue had been completely replaced by connective tissue that was highly infiltrated with lymphoid cells and macrophages. A slightly less severe reaction only indicated that there remained some recognizable splenic tissue which showed no signs of growth. The graft which experienced a mild host reaction had undergone growth and little differentiation. The splenic tissue had lost its myeloid character and looked more like red pulp with free erythrocytes in the meshes of splenic cords. There were no splenic nodules. Fragments of trabeculae were present and macrophages with engulfed erythrocytes were interspersed throughout the splenic tissue and concentrated at the junction between graft and kidney. Frequently these cells were seen within the kidney cortex in the vicinity of blood vessels.

\section{Ovary as second graft}

Grafts of ovary preceded by ovary. In the seven second-set grafts considered to have experienced no host reaction many large vesicular follicles had differentiated (fig. 13). Follicles were more numerous than in single grafts of comparable age, and follicular atresia was less. Proliferation of connective tissue was usually restricted to a band between the kidney and grafted ovary. All grafts were well vascularized. The one second-set graft which had undergone a severe homograft reaction was composed of a large amount of connective tissue interspersed with a few primary and secondary follicles. The graft which experienced a mild reaction had less connective tissue proliferation, but excessive when compared with well established ovarian grafts. Several large atretic, vesicular follicles were present and interstitial gland formation was pronounced.

The one first-set graft of ovary in this series which was severely affected was almost totally replaced by connective tissue. This graft preceded a second graft of ovary which had undergone a severe reaction. When the first graft was well established, the second graft was always well established too. Second grafts, however, generally grew and differentiated better than first grafts.

Grafts of ovary preceded by testis. After four weeks, differentiation in these second-set grafts of ovary (fig. 14) was better than in single grafts and was similar to the normal ovary of the same age. Hypertrophy of interstitial tissue, however, was a little more pronounced in the grafts. Three cases of multiovular follicles were observed in sections from three different grafts.

With the exception of one very severe reaction, all first-set grafts of testis looked like typical six-week single grafts. Some pycnotic primary spermatocytes were still present.

Grafts of ovary preceded by intestine. Five of the nine grafts recovered in this series experienced a homograft reaction classified as severe or very severe (fig. 15). Only two grafts had differentiated comparably to well established grafts of this age. When ovary was preceded by intestine, the severity of the reaction was greater than when ovary was preceded by either grafts of ovary (fig. 13) or testis (fig. 14). First grafts of intestine six weeks after implantation looked like single grafts. 
Grafts of ovary preceded by spleen. These second-set grafts of ovary (fig. 16) were much like the ones in the series where ovary was preceded by intestine, but the damage was slightly greater (table 2). Each degree of intensity of the homograft reaction has already been described.

Frequently the preceding splenic grafts had sloughed completely or degenerated severely. Only two of the ten splenic grafts implanted showed signs of growth with very little differentiation. These were classified as having undergone a mild reaction, previously described.

\section{Intestine as second graft}

Grafts of intestine preceded by intestine. No second-set grafts of intestine were recovered after four weeks.

All six first-set intestinal grafts had undergone degenerative changes comparable to those in six-week single grafts. Grafts which had experienced a very severe homograft reaction remained only as a ring of dense connective tissue surrounding the lumen. Occasionally small fragments of epithelial and muscular tissues were still attached to the inner surface of the connective tissue bordering the lumen. Sloughed epithelial cells, muscle cells, neutrophils, eosinophils, macrophages, and lymphoid cells were present in the lumen, which often contained a non-cellular debris. The host kidney cortex was always invaded by connective tissue. In grafts where the reaction was slightly less severe, only certain sections of the intestinal wall, associated with a heavy invasion of lymphoid cells, had sloughed into the lumen. Eosinophils were abundant in the remaining epithelium and lamina propria. In grafts where the reaction was mild practically all of the intestinal wall was intact, but degeneration and sloughing of cells were evident in areas invaded by lymphoid cells. Cell proliferation was still indicated by mitotic figures of many epithelial cells. Connective tissue, highly infiltrated with lymphocytes, was concentrated at the junction of graft and host kidney.

Seven additional hosts which had received similar grafts were autopsied two weeks after implantation of the second graft rather than after the usual fourweek period. Only two very severely dam- aged second grafts were recovered (fig. 17). Six of the seven first grafts of intestine recovered were comparable to fourweek single grafts.

Grafts of intestine preceded by testis. Three of the ten second-set intestinal grafts in this series showed extensive growth and differentiation of villi as well as of all layers of the intestinal wall (fig. 18). The epithelium was normal, and many cells were fixed in the process of dividing. Goblet cells were pronounced and Paneth cells with secretory granules were present. Connective tissue invasion was minimal. The remaining grafts were typical of the degenerating intestinal grafts already described.

First-set grafts of testis were apparently affected by the second graft of intestine even though they preceded the latter by two weeks. The general description of a first graft of testis in this series is very similar to the series in which testis was preceded by intestine (fig. 11). When seminiferous tubules were not too severely damaged, primary spermatocytes were present.

Grafts of intestine preceded by ovary. Second-set grafts of intestine (fig. 19) appeared very much like degenerating single grafts following four weeks of implantation. In general first-set ovarian grafts were not as normal as when ovary was followed by either testis or ovary. The host reaction to the ovary was very similar to that in animals where intestine preceded ovary (table 2). One multi-ovular follicle was found in each of two ovarian grafts in this series.

Grafts of intestine preceded by spleen. Only six highly degenerate grafts of the ten second-set grafts of intestine were recovered after four weeks (fig. 20), Eight of the first grafts of spleen were recovered. Four of these showed signs of growth and little differentiation. All others were severely damaged.

\section{Spleen as second graft}

Grafts of spleen preceded by spleen. No traces of second-set grafts of spleen were found in any hosts after four weeks. First-set grafts following six weeks of implantation in these hosts were severely damaged or not recovered. 
Five additional hosts which received similar grafts were autopsied two weeks after placement of the second graft. At this time three highly degenerate second grafts were recovered. In one case connective tissue not only had replaced the graft but this connective tissue apparently had undergone fatty transformation at the free margin of the degenerate implant (fig. 21).

Grafts of spleen preceded by testis. Second grafts of spleen preceded by testis were no more affected than single grafts of spleen after four weeks. The homograft reaction varied from mild (fig. 22) to very severe.

First-set grafts of testis after six weeks were far more severely affected than single grafts of a comparable age. Most of these grafts highly resembled grafts of testis preceded by spleen (fig. 12). Primary spermatocytes were present if seminiferous tubules were not too degenerate.

Grafts of spleen preceded by ovary. Second grafts of spleen (fig. 23) developed slightly better than single grafts of the same age. The number of grafts exhibiting only a mild reaction is greater in this series than in any other (table 4).

First-set grafts of ovary varied from no reaction, when compared with single controls, to a very severe homograft reaction. Fifty per cent of these grafts were very severely damaged. There was no definite pattern of correlation between the intensities of the reactions of first and second grafts. One well established graft of ovary preceded a graft of spleen which experienced a very severe reaction. One double ovular follicle was observed in a graft very severely damaged while an atretic, triple ovular follicle was observed in a graft very mildly affected.

Grafts of spleen preceded by intestine. Only four of the ten second-set splenic grafts were recovered. These had undergone a severe or a very severe homograft reaction (fig. 24). The nine recovered first-set intestinal grafts were no different than six-week single grafts.

\section{DISCUSSION}

Host reactions against testis

The results reported in this thesis confirm Larkin's ('60) report that an initial graft of testis inhibits differentiation of primary spermatocytes in a second graft. To explain this result, Larkin postulated that "the host produces antibodies to proteins of differentiating cells of seminiferous tubules but not to the undifferentiated cells." Her theory is difficult to test experimentally, but it seems reasonable when one realizes that the differentiating epithelium of seminiferous tubules of the adult (Billingham, '58) forms proteins which elicit the production of autoantibodies (Freund, Lipton, and Thompson, '53; Katsh and Bishop, '58). Possibly the proteins of seminiferous tubules first become antigenic when primary spermatocytes begin to develop. First grafts of neonatal testis produce numerous primary spermatocytes, but the proteins resulting from this differentiation are possibly antigenic and hence provoke a specific immunity against primary spermatocytes. Second grafts of neonatal testis grew well but differentiation of primary spermatocytes in their seminiferous tubules may have been suppressed by the hypothesized immune reaction.

Second grafts of testis preceded by ovary generally grew and differentiated well, although primary spermatocytes were less numerous than in single grafts of the same age. Ovary seemed to have elcited only a weak immune response if any. Lewis ('41) found a relationship among alcohol-soluble antigens of beef corpora lutea, testis and brain. Since no corpora lutea were observed in ovarian homografts in these experiments, the fact that testicular grafts preceded by ovarian grafts developed relatively few spermatocytes suggests the possibility that even the ovary with relatively young follicles may produce an antigen similar to the testicular antigen hypothesized by Larkin.

First grafts of intestine or spleen preceding testis did not elicit a host immune reaction directed specifically against differentiation of spermatocytes. When testis was preceded by either intestine or spleen, testicular tissue in the second graft was severely damaged (table 1 ). If the remaining tubules were not too severely damaged, however, primary spermatocytes were found. It appears that the strongly antigenic tissues of spleen or intestine, 
TABLE 1

Host reactions with testis as second graft

\begin{tabular}{lccccccc}
\hline $\begin{array}{c}\text { 1st graft at 6 wks } \\
\text { 2nd graft at 4 wks }\end{array}$ & $\begin{array}{c}\text { Number } \\
\text { grafted }\end{array}$ & $\begin{array}{c}\text { Number } \\
\text { recovered }\end{array}$ & $\begin{array}{c}\text { Very } \\
\text { severe }\end{array}$ & Severe & Mild & $\begin{array}{c}\text { Very } \\
\text { mild }\end{array}$ & $\begin{array}{c}\text { No } \\
\text { reaction }\end{array}$ \\
\hline 1st graft testis & 10 & 10 & 0 & 0 & 0 & 0 & 10 \\
2nd graft testis & 10 & 10 & 0 & 0 & 0 & 10 & 0 \\
1st graft ovary & 9 & 9 & 1 & 2 & 2 & 0 & 4 \\
2nd graft testis & 9 & 9 & 1 & 1 & 4 & 1 & 2 \\
1st graft intestine & 9 & 6 & 3 & 3 & 0 & 0 & 0 \\
2nd graft testis & 9 & 9 & 6 & 0 & 1 & 2 & 0 \\
1st graft spleen & 7 & 6 & 4 & 1 & 1 & 0 & 0 \\
2nd graft testis & 7 & 6 & 4 & 2 & 0 & 0 & 0 \\
\hline
\end{tabular}

'Second grafts of testis well established but differentiation of primary spermatocytes inhibited.

TABLE 2

Host reactions with testis as second graft

\begin{tabular}{lccccccc}
\hline $\begin{array}{c}\text { 1st grafts at 6 wks } \\
\text { 2nd grafts at 4 wks }\end{array}$ & $\begin{array}{c}\text { Number } \\
\text { grafted }\end{array}$ & $\begin{array}{c}\text { Number } \\
\text { recovered }\end{array}$ & $\begin{array}{c}\text { Very } \\
\text { severe }\end{array}$ & Severe & Mild & $\begin{array}{c}\text { Very } \\
\text { mild }\end{array}$ & $\begin{array}{c}\text { No } \\
\text { reaction }\end{array}$ \\
\hline 1st graft ovary & 10 & 9 & 1 & 2 & 2 & 0 & 4 \\
2nd graft ovary & 10 & 9 & 0 & 1 & 1 & 0 & 7 \\
1st graft testis & 10 & 10 & 1 & 0 & 0 & 2 & 7 \\
2nd graft ovary & 10 & 10 & 0 & 1 & 0 & 0 & 9 \\
1st graft intestine & 9 & 9 & 7 & 1 & 1 & 0 & 0 \\
2nd graft ovary & 9 & 9 & 3 & 2 & 2 & 0 & 2 \\
1st graft spleen & 10 & 6 & 3 & 1 & 2 & 0 & 0 \\
2nd graft ovary & 10 & 9 & 4 & 3 & 1 & 1 & 0 \\
\hline
\end{tabular}

both of which contain lymphoid cells, have provoked a non-specific immune reaction in the host. Although a second graft of testis became very degenerate, the immune reaction that is hypothesized seemed not to have been directed specifically toward the inhibition of spermatocyte production.

\section{Host reaction against ovary}

Second grafts of ovary preceded by ovarian grafts generally grew and differentiated well. Primary grafts of ovary in these experiments varied in their reaction. Some grew well and others degenerated (table 2). One wonders whether the apparently better development of second grafts can be explained by the phenomenon of enhancement. Breward and Zuckerman ('49), in their study on the reaction of the body to multiple ovarian grafts in normal adult female rats, found that grafts took better in animals implanted with six than in animals implanted with only two additional ovaries. Parkes
('58) observed that the acceptance and survival of interstrain ovarian grafts were enhanced by pretreatment of the recipient with suspensions of similar ovarian tissue. Although the reaction resembled that of tumor enhancement, Parkes was not certain that the mechanism was the same.

Second grafts of ovary preceded by testis grew exceptionally well for four weeks after implantation. The initial grafts of testis in the same hosts usually resembled single grafts grown for six weeks. If there is an antigen in the ovary which might elicit antibodies against spermatocyte differentiation, as discussed above, it appears not to affect differentiation of testis after it has once become established as a first graft.

Intestine or spleen preceding a homograft of ovary resulted in a host reaction which damaged the ovarian graft. Both of these organs elicited such a strong response that even single grafts of them generally degenerated rapidly. Their effect on second grafts of ovary as well as testis is 
an indication that they elicit a non-specific reaction.

The observation of multiovular follicles in some of the differentiating ovarian grafts was by chance. Serial sections were not made; hence these observations were made on sections of tissue selected at random. Hartman ('26) explained multiovular follicles as due to accidents in development, resulting from variable proportions of germ cells, epithelium, and stroma. Hartman (op. cit) and Harrison ('49) suggested atresia as an explanation, yet Corner ('23), from his observations on pig ovaries, indicated that multiovular follicles may reach maturity and ovulate. Bacsich ('46) suggested that they result from the postnatal withdrawal of the influence of maternal gonadtropin. More recently Kent ('62) has given considerable attention to these atypical ovarian structures and has explained his data on the basis that levels of estrogen and progesterone affect the incidence of polyovular and multinucleate follicles and that both estrogen production and primary and secondary follicular development may be correlated with FSH and LH levels. No conclusive explanation can be made for results obtained from the randomly selected material in this work. Eight multiovular follicles in eight different double grafts were observed in various graft combinations with the exception of ovary preceded by ovary. Grafting experiments, now under investigation, possibly may provide important clues toward elucidating the causal factors which underlie development of atypical follicles.

\section{Host reactions against spleen and intestine}

Both spleen and intestine provoked severe immune reactions even as single grafts. When a graft of intestine was preceded by intestine, or when spleen was preceded by spleen, typical immune responses occurred. Second grafts were usually completely destroyed within a period of four weeks or less; first grafts persisted, although they were degenerate. It seems likely that the lymphoid cells in the intestine may account for the similarity of reaction to both spleen and intestine. When spleen was grafted antecedent to implantation of intestine, or vice versa, both first and second grafts were destroyed by the host antibody response. Second grafts, whether of spleen or of intestine in these combinations, were more rapidly destroyed. The immune reaction appeared to be somewhat more severe when a given type of graft was preceded by one of its own kind (tables 3 and 4 ). The results indicate that spleen and intestine share some common antigens; yet the slightly more severe immunity reaction against like organs suggests some degree of organ specificity.

As previously mentioned, when testis or ovary preceded either intestine or spleen in double grafting combinations, the gonadal tissues were markedly affected by a host reaction. The fate of either ovary or testis as a first graft was similar to their fates as second grafts, when preceded by spleen or intestine. Intestine and spleen evidently are strongly antigenic and probably evoke an immune response which

TABLE 3

Host reactions with intestine as second graft

\begin{tabular}{lccccccc}
\hline $\begin{array}{c}\text { 1st grafts at 6 wks } \\
\text { 2nd grafts at 4 wks }\end{array}$ & $\begin{array}{c}\text { Number } \\
\text { grafted }\end{array}$ & $\begin{array}{c}\text { Number } \\
\text { recovered }\end{array}$ & $\begin{array}{c}\text { Very } \\
\text { severe }\end{array}$ & Severe & Mild & $\begin{array}{c}\text { Very } \\
\text { mild }\end{array}$ & $\begin{array}{c}\text { No } \\
\text { reaction }\end{array}$ \\
\hline 1st graft intestine & $\mathbf{6}$ & 6 & 3 & 2 & $\mathbf{1}$ & 0 & 0 \\
2nd graft intestine & $\mathbf{6}$ & $\mathbf{0}$ & $\mathbf{0}$ & 0 & 0 & 0 & 0 \\
1st graft testis & 10 & 10 & 2 & 4 & $\mathbf{1}$ & 0 & 3 \\
2nd graft intestine & $\mathbf{1 0}$ & 10 & $\mathbf{2}$ & $\mathbf{5}$ & $\mathbf{1}$ & 0 & $\mathbf{2}$ \\
1st graft ovary & $\mathbf{1 0}$ & $\mathbf{1 0}$ & $\mathbf{2}$ & $\mathbf{3}$ & $\mathbf{1}$ & $\mathbf{1}$ & 3 \\
2nd graft intestine & $\mathbf{1 0}$ & $\mathbf{8}$ & $\mathbf{5}$ & $\mathbf{2}$ & $\mathbf{1}$ & 0 & 0 \\
1st graft spleen & 10 & $\mathbf{8}$ & $\mathbf{2}$ & $\mathbf{2}$ & $\mathbf{4}$ & 0 & 0 \\
2nd graft intestine & 10 & $\mathbf{6}$ & $\mathbf{6}$ & $\mathbf{0}$ & $\mathbf{0}$ & $\mathbf{0}$ & $\mathbf{0}$ \\
\hline
\end{tabular}


TABLE 4

Host reactions with spleen as second graft

\begin{tabular}{|c|c|c|c|c|c|c|c|}
\hline $\begin{array}{l}\text { 1st graft at } 6 \text { wks } \\
\text { 2nd graft at } 4 \text { wks }\end{array}$ & $\begin{array}{c}\text { Number } \\
\text { grafted }\end{array}$ & $\begin{array}{l}\text { Number } \\
\text { recovered }\end{array}$ & $\begin{array}{l}\text { Very } \\
\text { severe }\end{array}$ & Severe & Mild & $\begin{array}{l}\text { Very } \\
\text { mild }\end{array}$ & $\begin{array}{l}\text { No } \\
\text { reaction }\end{array}$ \\
\hline $\begin{array}{l}\text { 1st graft spleen } \\
\text { 2nd graft spleen }\end{array}$ & $\begin{array}{l}5 \\
5\end{array}$ & $\begin{array}{l}3 \\
0\end{array}$ & $\begin{array}{l}1 \\
0\end{array}$ & $\begin{array}{l}2 \\
0\end{array}$ & $\begin{array}{l}0 \\
0\end{array}$ & $\begin{array}{l}0 \\
0\end{array}$ & $\begin{array}{l}0 \\
0\end{array}$ \\
\hline $\begin{array}{l}\text { 1st graft testis } \\
\text { 2nd graft spleen }\end{array}$ & $\begin{array}{l}10 \\
10\end{array}$ & $\begin{array}{r}10 \\
6\end{array}$ & $\begin{array}{l}6 \\
2\end{array}$ & $\begin{array}{l}1 \\
2\end{array}$ & $\begin{array}{l}3 \\
2\end{array}$ & $\begin{array}{l}0 \\
0\end{array}$ & $\begin{array}{l}\mathbf{0} \\
\mathbf{0}\end{array}$ \\
\hline $\begin{array}{l}\text { 1st graft ovary } \\
\text { 2nd graft spleen }\end{array}$ & $\begin{array}{l}10 \\
10\end{array}$ & $\begin{array}{l}10 \\
10\end{array}$ & $\begin{array}{l}5 \\
\mathbf{2}\end{array}$ & $\begin{array}{l}2 \\
3\end{array}$ & $\begin{array}{l}1 \\
5\end{array}$ & $\begin{array}{l}1 \\
0\end{array}$ & $\begin{array}{l}1 \\
0\end{array}$ \\
\hline $\begin{array}{l}\text { 1st graft intestine } \\
\text { 2nd graft spleen }\end{array}$ & $\begin{array}{l}10 \\
10\end{array}$ & $\begin{array}{l}9 \\
4\end{array}$ & $\begin{array}{l}8 \\
2\end{array}$ & $\begin{array}{l}0 \\
2\end{array}$ & $\begin{array}{l}1 \\
0\end{array}$ & $\begin{array}{l}\mathbf{0} \\
\mathbf{0}\end{array}$ & $\begin{array}{l}0 \\
0\end{array}$ \\
\hline
\end{tabular}

affects the less antigenic grafts of ovary or testis even after the latter have become well established.

\section{Influence of graft on host renal cortex}

Connective tissue frequently invaded the host renal cortex adjacent to the graft, resulting in degeneration of uriniferous tubules. This invasion usually was associated with grafts which themselves were degenerating. One explanation for this is a graft-versus-host reaction in the manner reviewed by Billingham ('59). Dempster ('53a) observed that in homotransplanted kidney the reticulo-endothelial system of the graft began to produce plasma cells even before the host developed any against the graft. $\mathrm{He}$ envisaged this plasma cell reaction as an indication of possible antibody formation against the host. On the other hand, Porter and Calne ('60) have used an autoradiographic technique in conjunction with tritium-labeled thymidine to trace the origin of infiltrating pyronine-positive cells in skin and kidney homografts. Many of these cells have been clearly shown to be of host origin. In the present experiments grafts were implanted at an age when lymphoid cells either had not reached full competency or had not become numerous enough to elcit a strong immune reaction (Howard and Michie, '62). Grafts of organs containing abundant lymphoid cells, e.g., spleen and intestine, underwent extensive regression. It seems likely that an immune response by the host initiated destruction before immunologically compentent cells of the graft could start to produce antibodies inimical to host tissues. Unfortunately tissues of the host other than renal tissue surrounding the graft were not examined. It is possible that graft antibodies against host antigens would affect host tissues far removed from the site of transplantation.

Another explanation is that stroma of the kidney was stimulated to proliferate so extensively that epithelium of renal tubules was crowded out or displaced. Greene ('55) has pointed out that if a graft is to be established successfully, it must have stroma-inducing properties, and the host must be the source of proliferating stromal cells. The host tissue at the site of transplantation must, in turn, be responsive to the stroma-inducing stimulus of the graft. Induction of proliferation of stroma in the kidney cortex, rather than production of anti-host antibodies by graft tissues, could explain the apparent invasion of connective tissue which replaced uriniferous tubular components at the site of implantation.

\section{SUMMARY}

1. Single homografts of testis, ovary, intestine, and spleen from four-day-old newborn rats were implanted beneath the kidney capsule of the adult male albino rat and allowed to grow for periods of two, four, and six weeks. Double homografts involving every possible pairing of grafts from the four donor organs were implanted similarly. Second grafts were implanted two weeks after first grafts and hosts were sacrificed after four weeks. The extent of growth and differentiation in single grafts served as a control for determining the differentiation of first- and second-set grafts of the four donor organs. 
2. In confirmation of Larkin's ('60) work, it was found that second grafts of testis preceded by testis grew well but were inhibited with respect to the differentiation of primary spermatocytes. First grafts differentiated much as single grafts of comparable age. Second grafts of testis preceded by ovary developed fewer spermatocytes than normal. Testis preceded by either intestine or spleen underwent regression.

3. In hosts receiving double ovarian implants, second grafts generally grew and continued differentiation better than did first grafts or single grafts, but first grafts developed better than single grafts of a comparable age. Second grafts of ovary preceded by testis developed exceptionally well, while the testis developed as when grafted singly. Ovary preceded by either spleen or intestine underwent some degeneration and invasion by connective tissue. Multiovular follicles were observed in several grafts of ovary paired with either testis, intestine or spleen but not paired with ovary.

4. Second grafts of intestine preceded by intestine or spleen preceded by spleen were completely destroyed within four weeks; a degenerate first graft persisted. Second grafts of intestine preceded by spleen or vice versa were destroyed but not as rapidly as when the first graft was from the homologous organ. These results suggest some degree of specificity in the immune reaction initiated by intestine as well as by spleen. When second grafts of intestine or spleen were preceded by either testis or ovary, the initially grafted testis or ovary in these combinations were caused to degenerate. Second grafts of intestine or spleen behaved much like single grafts.

5. The results of the experiments are interpreted in the light of current knowledge of actively acquired immunity.

\section{ACKNOWLEDGMENTS}

The author is deeply grateful to Dr. Norman E. Kemp for his valuable advice in directing and criticizing this work.

\section{LITERATURE CITED}

Amos, D. B., P. A. Gorer and B. W. Mikulska 1954 Immunity. Transpl. Bull., 1: 92-93.

Bacsich, P. 1946 Multinuclear ova and multiovular follicles in the young human ovary. J. Anat,, 80: 243-244.
Billingham, R. E. 1958 Actively acquired tolerance and its role in development. W. D. McEIroy and B. Glass, eds. W. B. Saunders Co., Philadelphia, pp. 575-592.

- 1959 Reactions of grafts against their hosts. Science, 130: 947-953.

Billingham, R. E., L. Brent and P. B. Medawar 1954 Quantitative studies on tissue transplantation immunity. II. The origin, strength and duration of actively and adoptively acquired immunity. Proc. Roy. Soc. London, B, 143: $58-80$.

- 1956a Quantitative studies on tissue transplantation. III. Actively acquired tolerance. Philos. Trans. Roy. Soc. London, B, 239: $357-414$.

$1956 \mathrm{~b}$ The antigenic stimulus in transplantation immunity. Nature, 178: 514-519.

Billingham, R. E., L. Brent, P. B. Medawar and E. M. Sparrow 1954 Quantitative studies on tissue transplantation immunity. I. The survivial time of skin homografts exchanged between members of different inbred strains of mice. Proc. Roy. Soc. London, B, 143: 43-57.

Billingham, R. E., and A. S. Parkes 1955 Studies on the survival of homografts of skin and ovarian tissue in rats. Ibid., 143: 550-560.

Billingham, R. E., and W. K. Silvers 1961 Quantitative studies on the ability of cells of different origins to induce tolerance of skin homografts and cause runt disease in neonatal mice. J. Exp. Zool., 146: 113-129.

Billingham, R. E., W. K. Silvers and D. B. Wilson 1962 Adoptive transfer of transplantation im. munity by means of blood-borne cells. Lancet, I: $512-515$.

Brent, L., J. B. Brown and P. B. Medawar 1959 Skin transplantation immunity in relation to hypersensitivity reactions of the delayed type. In: Biological Problems of Grafting. F. Albert and $G$. Lejeune-Ledant, eds. Charles $C$ Thomas, Springfield, Illinois, pp. 64-84.

Breward, M. M., and S. Zuckerman 1949 The reaction of the body to multiple ovarian grafts. J. Endocrin., 6: 226-234.

Castermans, A. 1958 Reevaluation of a pretreatment given to adult animals to modify their responsiveness to skin homografts. Transpl. Bull., 5: 381-387.

Chutná, J. 1961 White-graft reaction and passive transfer of immunity in inbred strains of mice. Ibid., 28: 23-25.

Corner, G. W. 1923 The problems of embryonic pathology in mammals, with observations upon intrauterine mortality in the pig. Am. J. Anat., 31: 523-545.

Crouse, G. S. 1956 Differentiation of intracerebral implants of rudiments from rat and mouse embryos in young rats. Anat. Rec., 135: $215-394$.

Davis, J. S. 1917 Some of the problems of plastic surgery. Ann. Surg., 66: 88-94.

Dempster, W. J. 1953a Kidney homotransplantation. Brit. J. Surg., 40: 447-465.

1953b The relationship between the antigens of skin and kidney of dog. Brit. J. Plastic Surg., 5: 228-237. 
Freund, J. M., M. M. Lipton and G. E. Thompson 1953 Aspermatogenesis in the guinea pig induced by testicular tissue and adjuvant. J. Exp. Med., 97: 711-726.

Gibson, T., and P. B. Medawar 1943 The fate of skin homografts in man. J. Anat., 77: 299310.

Gorer, P. A. 1955 The antibody response to skin homografts in mice. Ann. N. Y. Acad. Sci., 59: 365-373.

1956 Some recent work on tumor im munity. Ad. Cancer Res., IV: 149-186.

Greene, H. S. N. 1955 Compatibility and noncompatibility in tissue transplantation. In: Biological Specificity and Growth. E. G. Butler, ed. Princeton Univ. Press, Princeton, pp. 177194.

Hargitt, G. T. 1926 The formation of the sex glands and germ cells of mammals. II. The history of the male germ cells in the albino rat. J. Morph. and Physiol., 42: 253-306.

Harris, M., and R. M. Eakin 1949 Survival of transplanted ovaries in rats. J. Exp. Zool. 112: 131-161.

Harrison, R. J. 1949 Multiovular follicles in the ovaries of lower primates. Nature, 164 409-410.

Hartman, C. G. 1926 Polynuclear ova and polyovular follicles in the opossum and other mammals, with special reference to the problem of fecundity. Am. J. Anat., 37: 1-52.

Holman, E. 1924 Protein sensitization in isoskingrafting. Is the latter of practical value? Surg. Gyne., and Obstet., 38: 100-106.

Howard, J. G., and D. Michie 1962 Induction of transplantation immunity in the newborn mouse. Transpl. Bull., 29: 91-96.

Kaliss, N. 1955 Reversal of the "second set response" in tumor transplantation. Transpl. BuIl., 2: 52-53.

Kammeraad, A. 1942 The development of the gastro-intestinal tract of the rat. II. Homotransplantation of embryonic and adult gastrointestinal tract mucosa of the rat to the anterior chamber of the eye. J. Exp. Zool., 91: 4563.

Katsh, S., and D. W. Bishop 1958 The effects of homologous testicular and brain and heterologous testicular homogenates combined with adjuvants upon the testes of guinea pigs. J. Embryol. Exp. Morph., 6: 94-104.

Kent, H. A. 1962 Polyovular follicles and multinucleate ova in ovaries of young rats. Anat. Rec., 142: 25-29.

Krohn, P. L. 1958 Litters from C3H and CBA ovaries orthotopically transplanted into tolerant A strain mice. Nature, 181: 1671-1672.

Larkin, J. H. 1960 Differentiation of first- and second-set grafts of embryonic, neonatal and adult testis implanted beneath the kidney capsule of adult rat hosts. Am. J. Anat., 106: 73-88.

Lawrence, H. S. 1960 Delayed sensitivity and homograft sensitivity. Annual Rev. Med., 11: $207-230$.

Lawrence, H. S., F. T. Rapaport, J. M. Converse and W. S. Tillet 1960 Transfer of delayed hypersensitivity to skin homografts with leuko- cyte extracts in man. J. Clin. Invest., 39: 185-198.

Lewis, J. H. 1941 The antigenic relationship of alcohol-soluble substances of corpus luteum to those of testis and brain. Am. J. Path., 17: 725-730.

Lewis, T., J. E. Murray and N. P. Couch 1957 Consecutive skin homografts in the dog. Transpl. Bull., 4: 156-157.

Loeb, L. 1945 The Biological Basis of Individuality. Charles C Thomas, Springfield, Illinois.

Macintyre, M. N. 1956 Effect of the testis on ovarian differentiation in heterosexual embryonic rat gonad transplants. Anat. Rec., 124: $27-46$.

Masson, J. C. 1918 Skin grafting. J. Am. Med. Assoc., 70: 1581-1584.

Maximow, A. A., and W. Bloom 1957 A Textbook of Histology. Seventh ed. W. B. Saunders Co., Philadelphia.

Medawar, P. B. 1943 Notes on the problem of skin homografts. Bull. War Med., 4: 1-4. 1944 The behavior and fate of skin autografts and skin homografts in rabbits. J. Anat., 78: 176-199.

1945 A second study of the behavior and fate of skin homografts in rabbits. Ibid. 79: 157-176.

Medawar, P. B., and M. F. A. Woodruff 1958 The induction of tolerance by skin homografts on newborn rats. Immunology, 1: 27-35.

Parkes, A. S. 1958 Enhancement of the survival of interstrain ovarian homografts in rats. Transpl. Bull., 5: 45-57.

Porter, K. A., and R. Y. Calne 1960 Origin of the infiltrating cells in skin and kidney homografts. Ibid., 26: $458-464$.

Schöne, G. 1912 Die heteroplastische and homoöplastísche Transplantation. J. Springer, Berlin.

Simonsen, M. 1955 The acquired immunity concept in kidney homotransplantation. Ann. N. Y. Acad. Sci., 59: 448-452.

Snell, G. D., A. M. Cloudman, E. Failor and P. Douglas 1946 Inhibition and stimulation of tumor homoiotransplants by prior injections of lyophilized tumor tissue. Nat. Cancer Inst., 6: 303-316.

Snell, G. D., H. J. Winn, J. H. Stimpfling and S. J. Parker 1960 Depression by antibody of the immune response to homografts and its role in immunological enhancement. J. Exp. Med., 112: 293-314.

Steinmuller, D. 1961a Transplantation immunity in the newborn rat. $I$. The response at birth and maturation of response capacity. J. Exp. Zool., 147: 233-257.

$1961 \mathrm{~b}$ Transplantation immunity in the newborn rat. II. The transfer of immunity to newborn recipients. Ibid., 148: 147-157.

Stetson, C. A., Jr., and R. Demopoulos 1958 Reactions of skin homografts with specific immune sera. Ann. N. Y. Acad. Sci., 73: 687-692.

Stone, H. B. 1942 The defense of the human body against living mammalian cells. Ann. Surg., 115: 883-891. 
Terasaki, P. I., J. A. Cannon and W. P. Longmire, Jr. 1960 Antibody response to homografts. IV. Time of appearance of lymphoagglutinins in partially tolerant animals. Transpl. Bull., 7 (25): 415-518.
Woodruff, M. F. A., and L. O. Simpson 1955 Induction of tolerance to skin homografts in rats by injection of cells from the prospective donor soon after birth. Brit. J. Exp. Path., 36: $494-499$.

PLATE 1

EXPLANATION OF FIGURES

Four-day-old neonatal donor organs

1 Section through testis. Solid seminiferous tubules have a peripheral layer of undifferentiated, small cells. Large cells in the interior are primordial germ cells which eventually degenerate. Tunica albuginea can be seen in the upper left corner of photograph. $\times 410$.

2 Section through ovary. Secondary cortex is divided into Pflüger's tubes containing oogonia devoid of follicle cells. The definitive medulla in the lower right of photograph is devoid of primordial germ cells. $\times 410$.

3 Portion of cross section through intestine. $\times 96$.

4 Section through spleen. Splenic nodules are not yet pronounced. $\times 96$. 

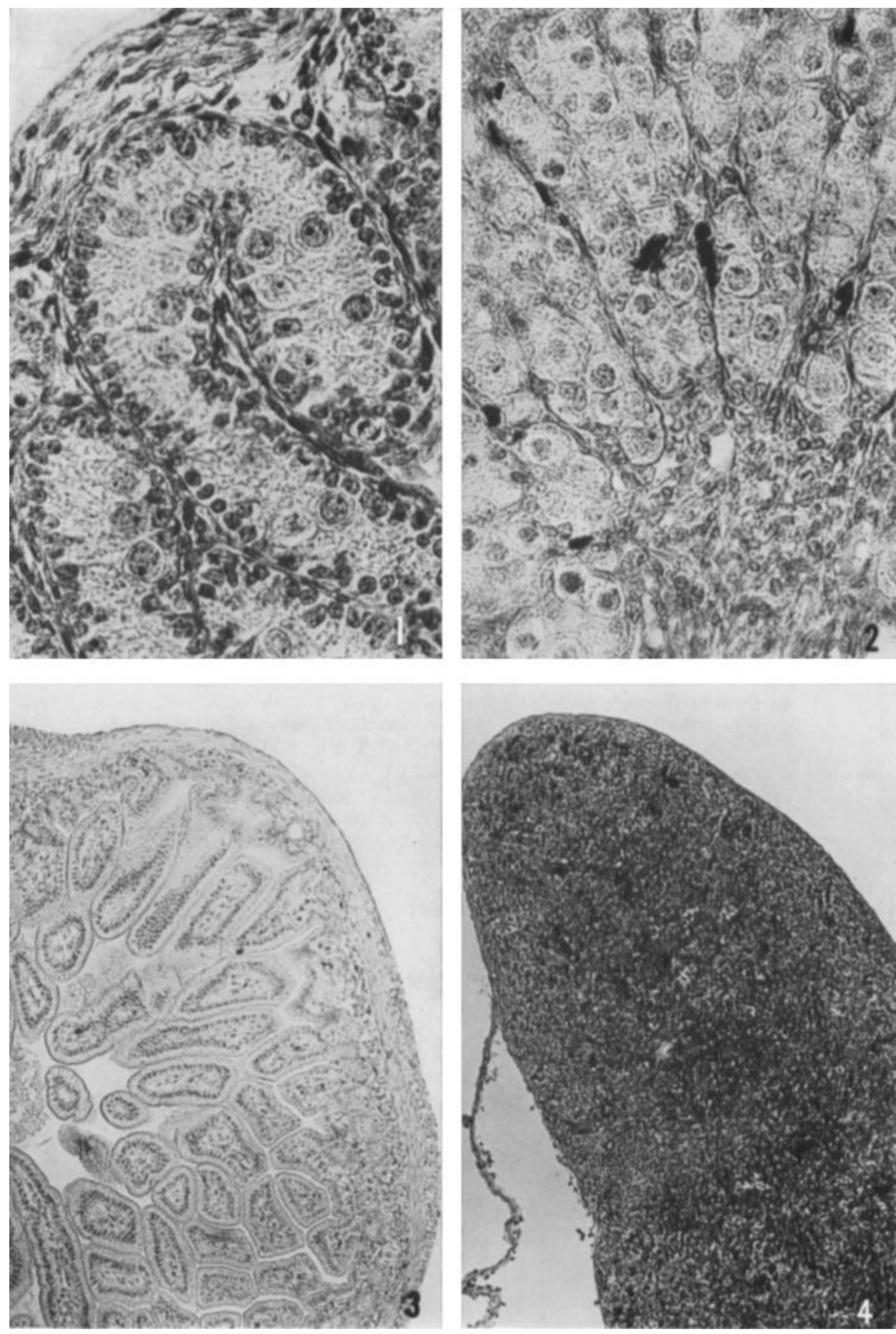
PLATE 2

EXPLANATION OF FIGURES

Four-week single grafts

5 Section through seminiferous tubules of grafted testis. Arrow points to primary spermatocytes in first meiotic division. $\times 492$.

6 Section through grafted ovary showing developing follicles. Host renal tissue to the left of graft. $\times 96$.

7 Section through graft of intestine showing Paneth cells with secretory granules (arrow) at bottom of glands of Lieberkühn. Host renal tissue is present at the lower border of graft. $\times 410$.

8 Degenerate graft of spleen. Arrow points to necrotic splenic tissue embedded in a mass of connective tissue. Host renal tissue is present in lower left corner of photograph. $\times 96$. 

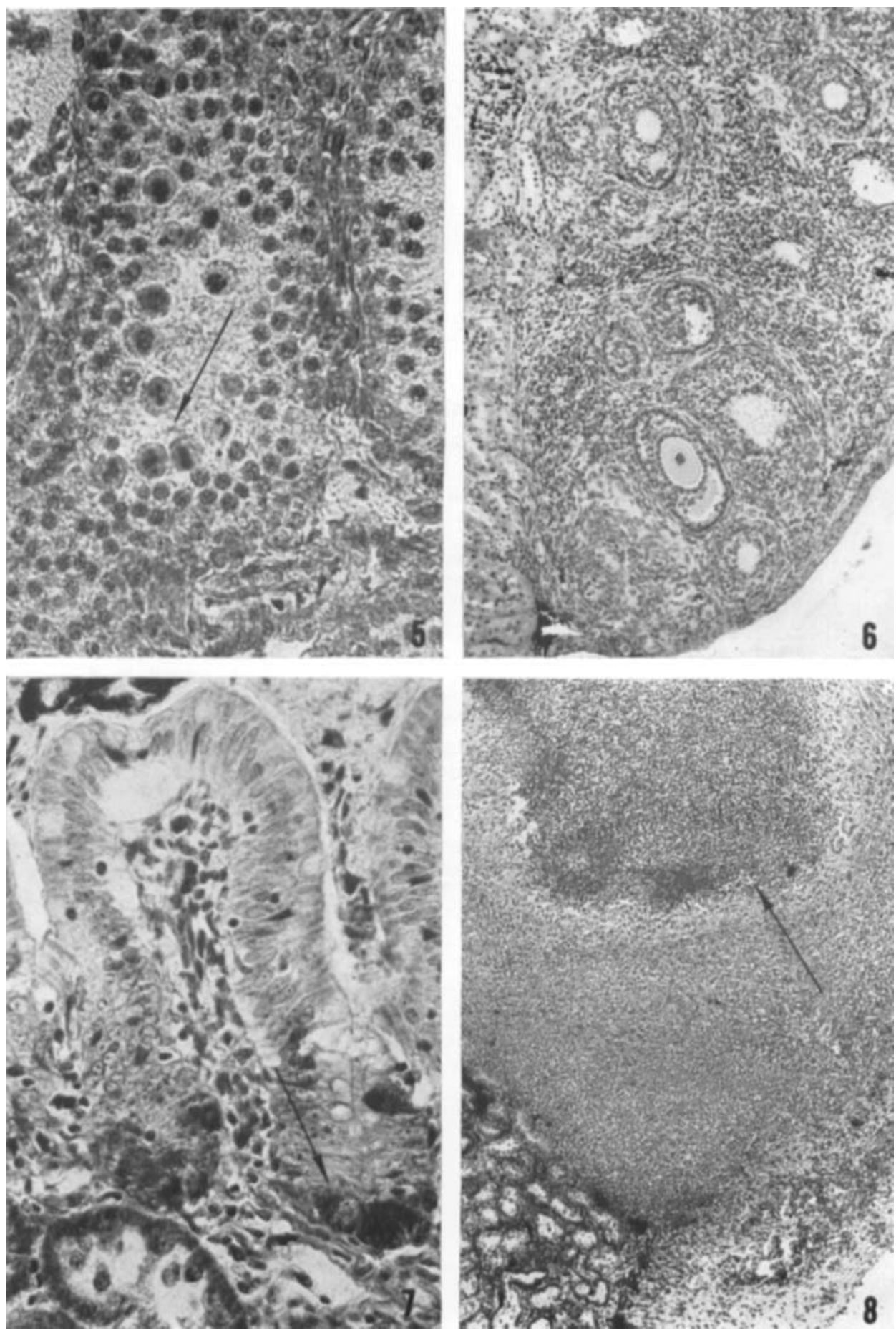
PLATE 3

EXPLANATION OF FIGURES

Testis as second graft

9 Four-week, second graft of testis which was preceded by testis. Note the absence of large primary spermatocytes in the seminiferous tubules. Section through a renal tubule of host in lower left corner of photograph. $\times 410$.

10 Four-week, second graft of testis which was preceded by ovary. Arrow points to a few large primary spermatocytes present in a section through one seminiferous tubule. Host renal tissue can be seen at lower edge of photograph. $\times 410$.

11 Four-week, second graft of testis which was preceded by intestine. Testicular tissue has been replaced by connective tissue. Arrow points to remnant of a seminiferous tubule. Note renal tissue below. Very severe host reaction. $\times 96$.

12 Four-week, second graft of testis which was preceded by spleen. Only a few degenerate seminiferous tubules remain. Note renal tissue below. Very severe host reaction. $\times 96$. 

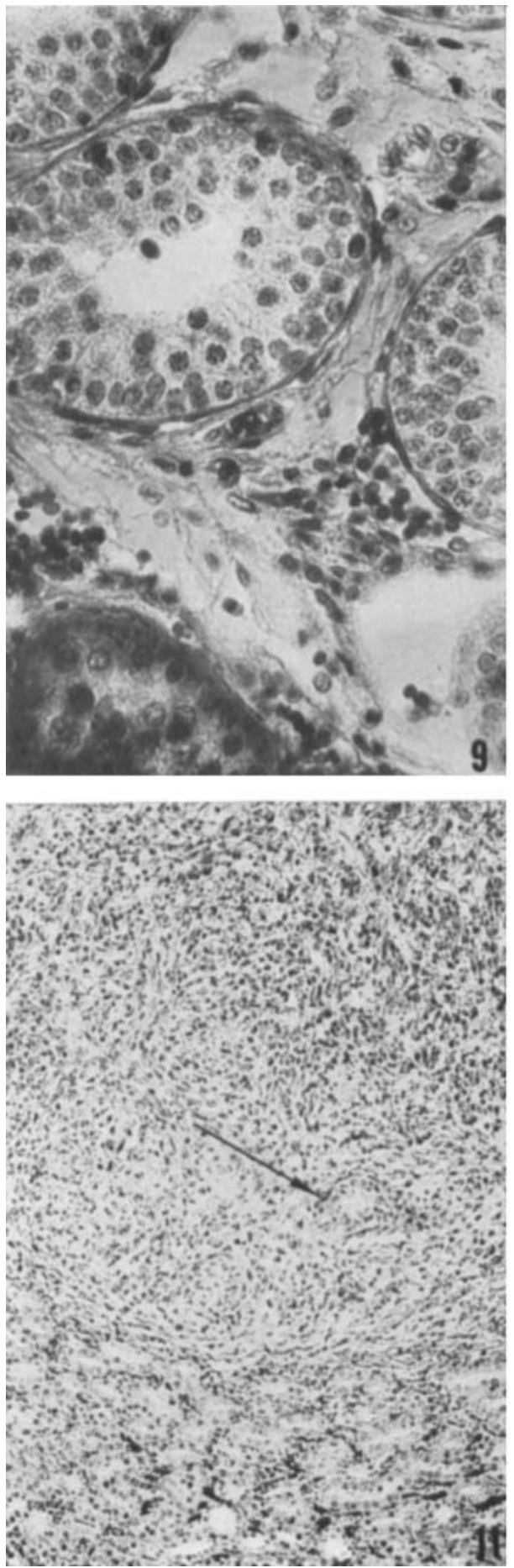
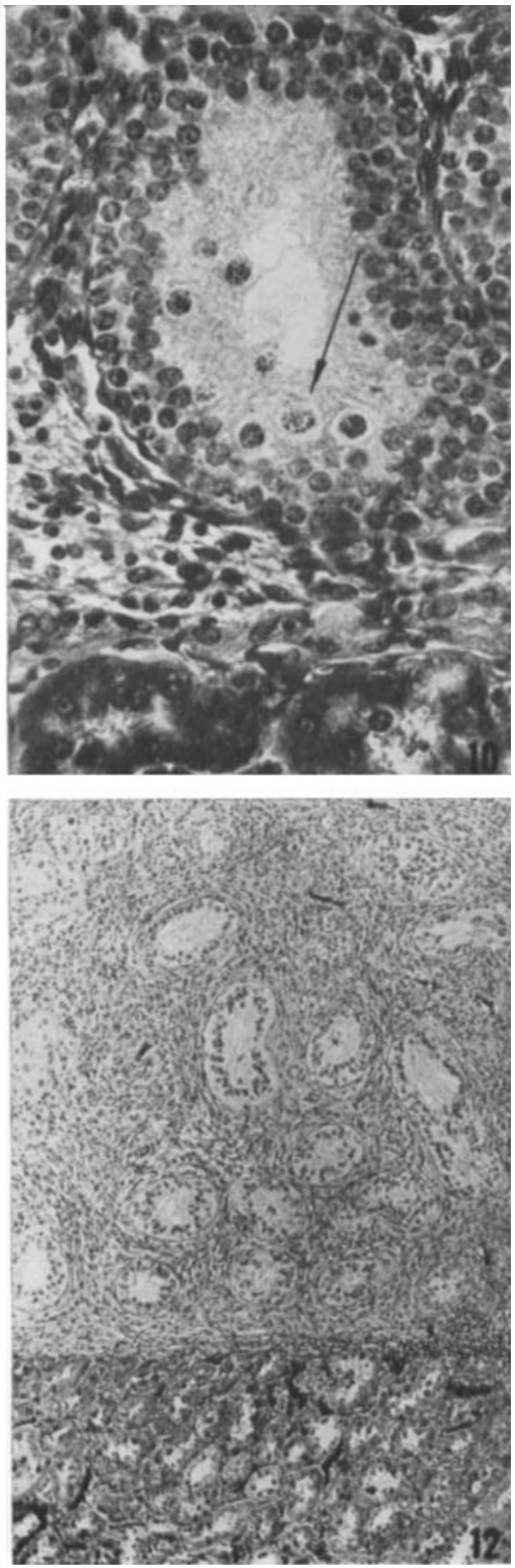
PLATE 4

EXPLANATION OF FIGURES

Ovary as second graft

13 Four-week, second graft of ovary which was preceded by ovary. Two large follicles show antra. Renal tissue of host is present below graft. $\times 96$.

14 Four-week, second graft of ovary which was preceded by testis. Arrow points to a double ovular follicle. Host renal tissue is below. $\times 96$.

15 Four-week, second graft of ovary which was preceded by intestine. Ovarian tissue has been replaced by connective tissue. Tubular structures in the connective tissue appear to be sections of oviduct which was probably implanted accidentally along with the ovary. Renal tissue of the host below with a large vascular area to the right. Very severe host reaction. $\times 96$.

16 Four-week, second graft of ovary which was preceded by spleen. An ovarian follicle remains in grafted tissue which has been largely replaced by connective tissue. Renal tissue in lower right corner of photograph. Very severe host reaction. $\times 96$. 

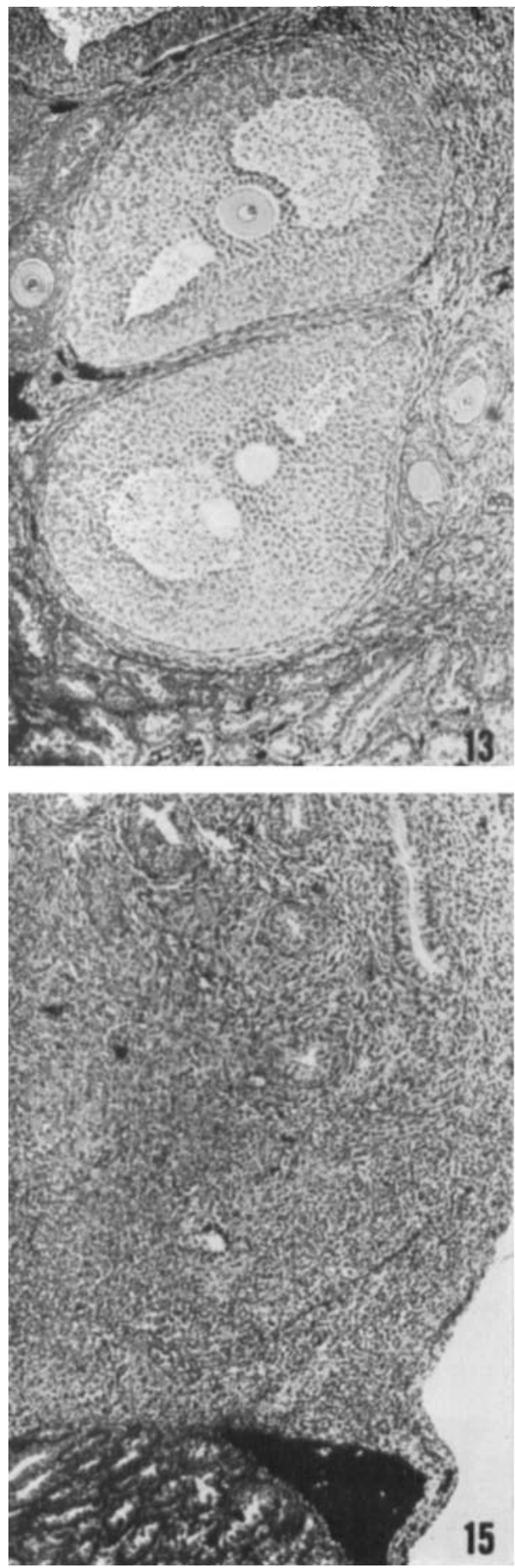
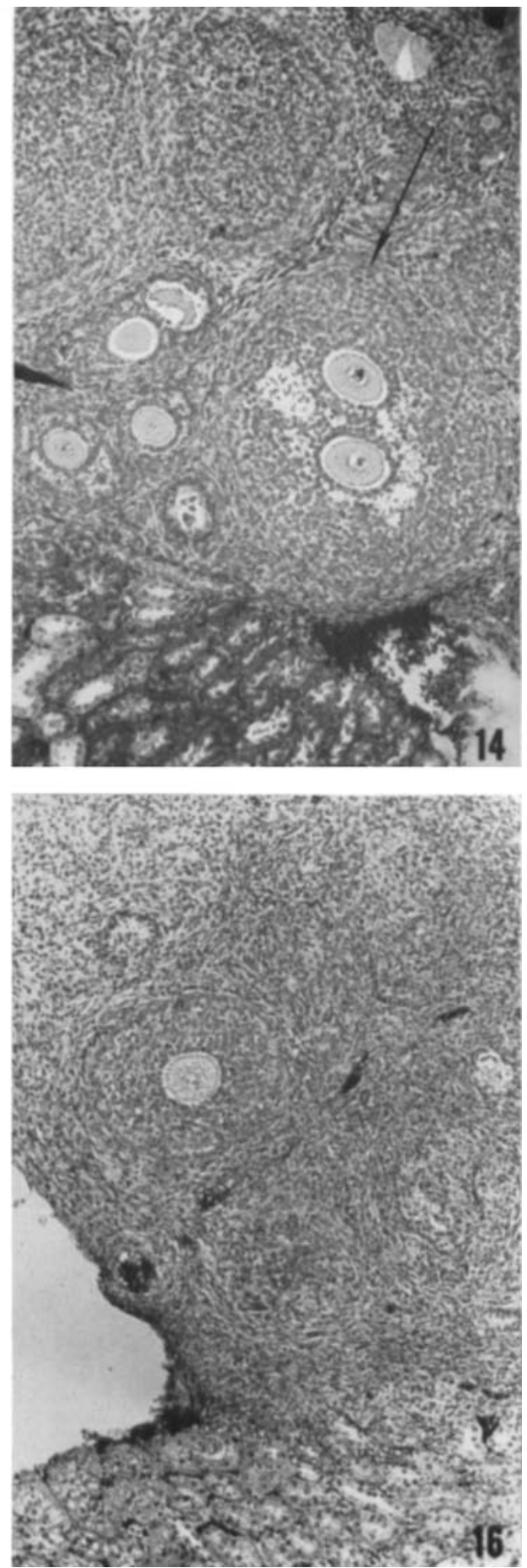
PLATE 5

EXPLANATION OF FIGURES

Intestine as second graft

17 Since no second grafts of intestine preceded by intestine persisted for four weeks, a two-week second graft of intestine preceded by intestine is illustrated. Graft remains only as a thick hollow ring of connective and muscular tissues attached to the host renal tissue. All epithelium has degenerated and sloughed into the lumen. Very severe host reaction. $\times 96$.

18 Four-week, second graft of intestine which was preceded by testis. Graft shows growth and differentiation of glandular epithelium (arrow) as well as all other layers of the intestinal wall. Adjacent renal tissue extends across the lower border and to the right of grafted intestine. Only mild host reaction against graft. $\times 96$.

19 Four-week, second graft of intestine which was preceded by ovary. Epithelium (arrow) bordering the lumen is highly degenerate and most of it has sloughed into the lumen. Connective and muscular tissues comprise most of graft. Very severe host reaction. $\times 96$.

20 Four-week, second graft of intestine which was preceded by spleen. Section of graft shows the most extensive amount of epithelium bordering lumen above. Note adjacent renal tissue below. Very severe host reaction. $\times 96$. 

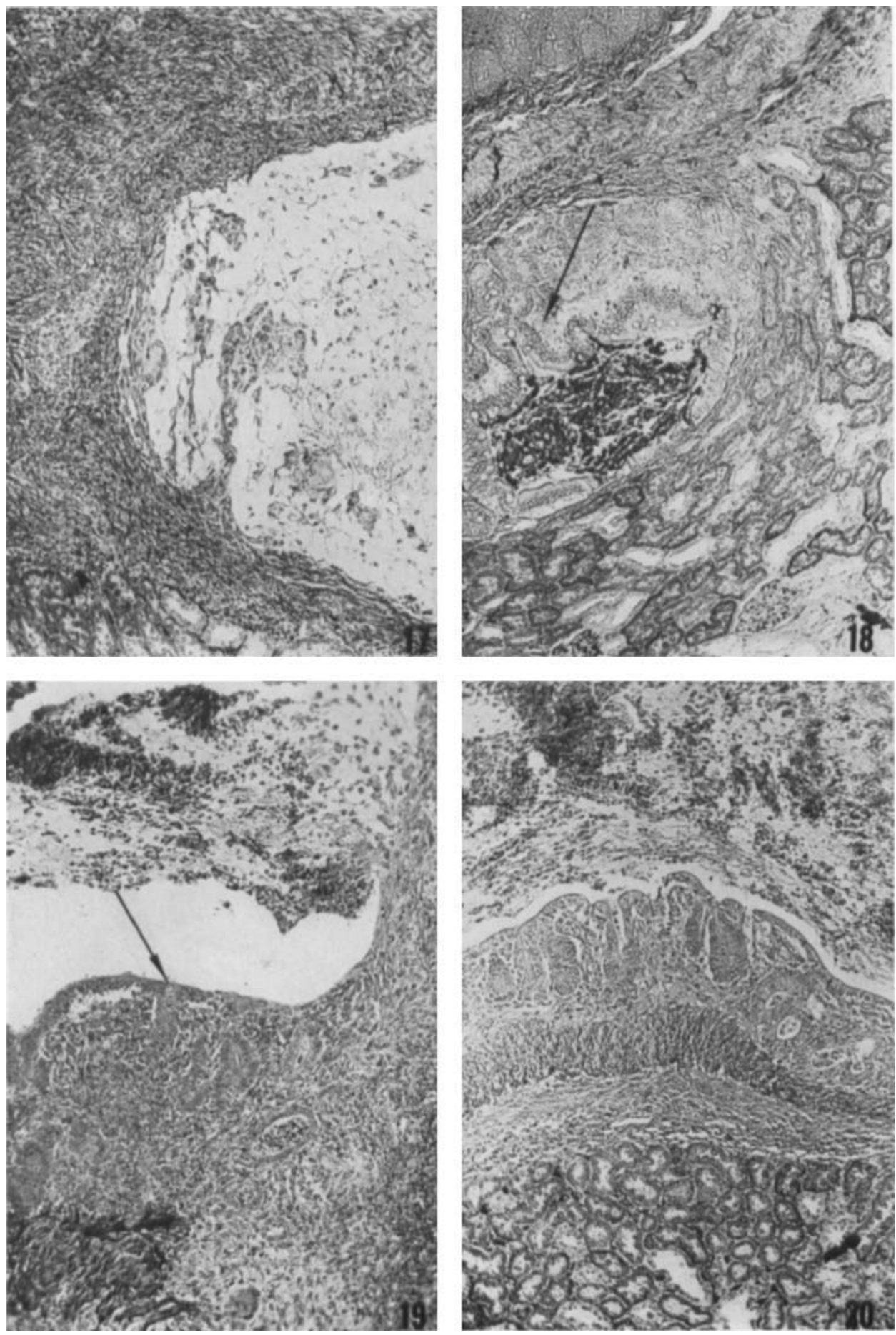
PLATE 6

EXPLANATION OF FIGURES

Spleen as second graft

21 Two-week, second graft of spleen which was preceded by spleen. Graft has been replaced by connective tissue at the free margin of which fat transformation has occurred. Note renal tissue in lower right corner of photograph. Very severe host reaction. $\times 96$.

22 Four-week, second graft of spleen which was preceded by testis. Graft has undergone growth and some differentiation. The black areas in the photograph are free erythrocytes. Mild host reaction. $\times 96$.

23 Four-week, second graft of spleen which was preceded by ovary. Adjacent renal tissue can be seen at the lower right corner of photograph. Mild host reaction. $\times 96$.

24 Four-week, second graft of spleen which was preceded by intestine. Graft is composed entirely of connective tissue. Very severe host reaction. $\times 96$. 

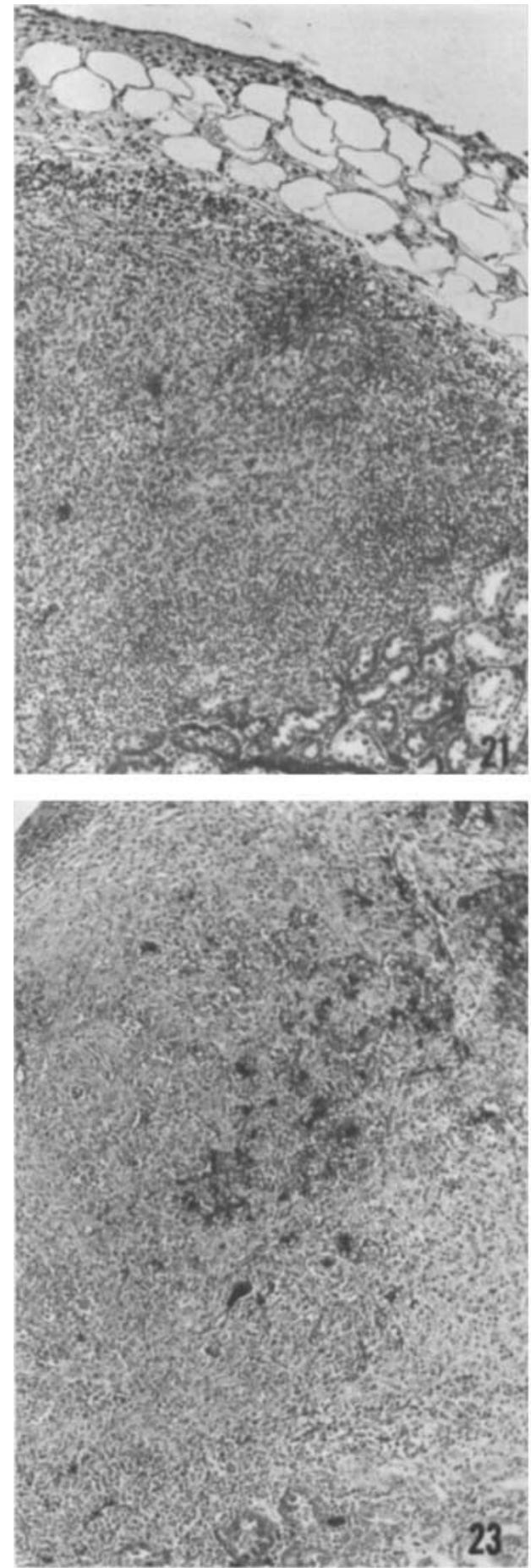
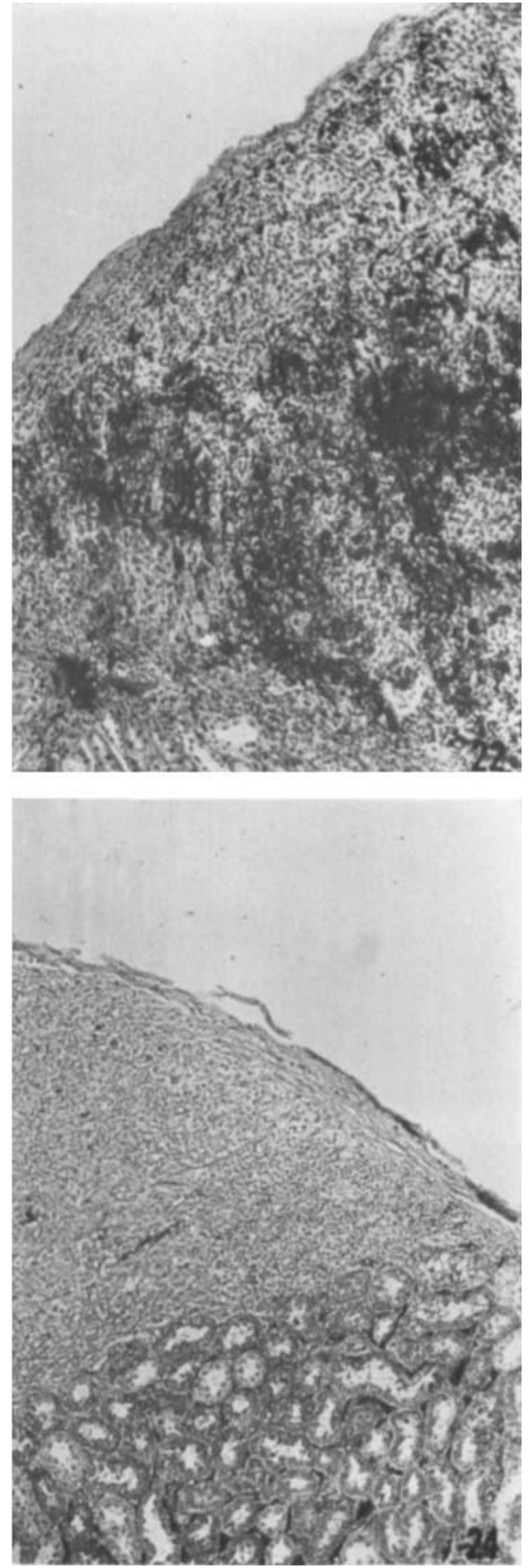